Derviş Tuğrul Koyuncu,

\title{
Osmanlı İmparatorluğu'nda İçki Üretimi ve Tüketimi,
}

İstanbul: Selenge Yayınları, 2020, 248 s., ISBN 978-605-4944-65-1.

Derviş Tuğrul Koyuncu'nun Selenge Yayınları tarafından 2020 yılında neşredilen "Osmanlı İmparatorluğu’nda İcki Üretimi ve Tüketimi" isimli kitabı, 15001839 yılları arasında Osmanlı İstanbul'unda gerçekleşen içki üretimi ve tüketiminin sosyal, iktisadi ve hukuki boyutlarını ve içki üretim ve tüketiminin tarihsel gelişimini inceleyerek bir ilke imza atmaktadır. Bu anlamda Müslüman bir imparatorluğun içki ile ilişkisini açıklığa kavuşturması, okuyucunun aklındaki birçok soruya cevap vermesi ve Osmanlı Arşivi'nden birçok belgenin grafik ve tablolarla desteklenmesi ile kitap orijinal bir eser olarak kaleme alınmıştır denilebilir.

Kitap üç ana bölümden oluşmaktadır. Bu ana bölümlerden ilki "İslam Hukukunda ve Osmanl Imparatorluğu’nda İçki; Tüketim Cezaları ve Vergilendirmenin Hukuki Kaynağı" olarak belirlenirken, ikinci ana bölüm "Osmanlı İmparatorluğu’nda Müskiratın Serüveni 1500-1839” ismiyle, üçüncü ana bölüm ise “Osmanlida Müskirat Üretimi, Ticareti ve Tüketimi: 1792-1839” başlı̆̆ıla okuyucuya sunulmaktadır. 
Altı alt başlıktan oluşan ilk bölümde Koyuncu, içkinin cezai ve hukuki dayanaklarını anlatarak okuyucuya içki tüketiminin ve üretiminin vergilendirme esaslarına ve İslam âlimlerin bu konu hakkındaki görüşlerini sunmaktadır. Bu bölümde işlenen öncelikli konu zimmet akdi olarak karşımıza çıkmaktadır. Müslümanların ve gayrimüslimlerin ödediği öşür, haraç, cizye gibi vergilerin kısa bir açılklaması okuyucuya sunulmakta ve sonrasında Osmanlı topraklarında yaşayan gayrimüslimlerin bir portresi çizilmektedir. Bunu gerçekleştirirken yazar, Aubry de La Mottraye ve Reinhold Lubenau gibi seyahatname yazarlarına başvurur. $\mathrm{Bu}$ noktada imparatorluğun sınıları içinde yaşayan gayrimüslimlerin giyimleri, ibadetleri, kuruluşları ve eğitimleri gibi uygulamaların kısa bir portresini okuyucuya sunar. Bundan sonra İslâm'ın ilk dönemlerinde alkolün Müslümanlara hangi ayetler ile haram kılındığı hatırlatılır. Müslüman bir devlet olan Osmanlı Devleti'nde Şer'i ve Örf’i hükümlere dayanarak alkolün Müslümanların rızkı olmadığı için tüketiminin ve üretiminin uygun bulunmadığı söylenmekte ve yasaklardan bahsedilmektedir. İmparatorluk çapında kanunnameler, içki üreten ve tüketenlere uygulanan cezanın belirlenmesinde etkili olmaktadır. Nitekim Fatih Kanunnamesinde içki içene kadı tarafından tazir cezası verileceği ve içki kullanandan, parasal bir ceza olarak iki sopaya bir akçe alınacağı belirtilmektedir. Şeriyye sicillerinden hareketle; haneye tecavüz, hırsızlık, hakaret, cinayet gibi suçların büyük çoğunluğunun alkollü kişiler tarafından meydana getirilmesi cezalandırmanın nedeni olarak öne çıkmaktadır.

İlk bölümde ayrıca içkinin vergilendirilmesi ve bu vergilendirmenin dinamiklerinin neler olduğu da açıklanmaya çalışılmıştır. Bu açıklama yapılırken İslâm’ın ilk dönemindeki uygulamalar incelenmiştir. İslâm'ın ilk döneminde gayrimüslimlerin kendilerine yetecek kadar içki üretimine ve tüketimine izin verilse de içkiden alınan vergide birtakım kurallar bulunmaktadır. Ensari Muhammed bin Abdullah, İslâm'ın ilk zamanlarında gayrimüslimlerden cizye karşılığında alınan domuzun ve içkinin, satılarak nakde çevrildiğini aktarmaktadır. Nitekim bu uygulama $H z$. Ömer tarafından yasaklamış, Ebu Ubeyd gibi isimler de bunu desteklemişlerdir. Bu noktada Hz. Muhammed' in "Allah bir şeyi haram etmişse o şeyin kıymetini de haram etmiştir" hadisi dikkat çekmektedir. Yine aynı bölümde İmam-ı Azam Ebu Hanife ve İmam Ebu Yusuf gibi alimlerin domuz ve içki gibi haram olan malların vergilendirilmesi hakkındaki görüşlerine de kitapta yer verilmiştir. İslam'da vergilendirme okuyucuya aktarıldıktan sonra Osmanlı Devleti'nde içkinin vergilendirilmesi incelenmiştir. Eğer üretim, şahsın kendi tüketimi için gerçekleşiyorsa öşür-i şıra ve resm-i fıçı ismi altında düşük 
miktarda vergi alınmaktadır. Ancak 1792 yılına kadar verginin tahsili bölgelere göre değişiklik göstermekte kimi yerlerde ad valorem şeklinde tahsil edilen vergi kimi yerlerde spesifik olarak tahsil edilmektedir. Yazar, bu konularda arşiv belgelerine dayanarak tarihsel süreç içerisinde farklı bölgelerde vergilendirmenin nasıl gerçekleştiğini anlatmaktadır. Vergilendirme ile ilgili dikkat çeken bir husus Osmanlı İmparatorluğu sınırları içerisinde müskiratın vergilendirilmesinin 18. yüzyıl sonuna kadar İstanbul Hamr ve Arak Mukataası dışında bir bütünlük gösterememiş olmasıdır.

"Osmanlı İmparatorluğunda Müskiratın Serüveni” başlıklı ikinci bölüm, 19. yüzyıla kadar müskiratın Osmanlı topraklarında hangi kanunlar ile yasaklandığını anlatmasına ek olarak bu durumun Osmanlı maliyesi üzerindeki etkisine değinmektedir. Nitekim Bizans döneminde kopepsler ve orgasterion olarak karşımıza çıkan alkol satış dükkânlarının ve Osmanlıdaki meyhanelerin kimi muhalif ve sisteme aykırı seslerin yükseldiği kamusal alanlar olarak görülmesinden sıkça bahsedilmekte ve yasakların nedeninin çoğunlukla halkın huzurunun kaçması olduğu, arşiv kaynaklarına dayanılarak çalışmada vurgulanmaktadır. İstanbul'un fethinden sonra 16. yüzyılda meyhaneler ile mücadele eden ilk padişah II. Beyazid'dir. Halefleri de içki tüketimini yasaklamışlardır. Kanuni Sultan Süleyman 1555 senesinde içki yasağı sonrası şarap yüklü gemilerin yakılması emrini vermiştir. Hatta Ogier Ghislain de Busbecq şarap tüketen birisi olarak paşalardan izin istemek zorunda kalmıştır. 16. yüzyılda da yasakların ana nedeni asayiş sorunları olarak karşımıza çıkmaktadır. 17. yüzyılda yasaklar devam ederken en sert önlem IV. Murat tarafından alınmıştır. Nitekim padişah tebdil-i kıyafet ile Bursa'ya geçerek yasaklarını denetlemiştir. 1670 senesinde yasaklanan müskirat 1688 senesinde mali sıkıntılardan dolayı yeni vergiler ile serbest bırakılırken, 1689 senesinde tekrar yasaklanmıştır. Bu durumun, Osmanlı maliyesinin içine düştüğü mali sıkıntılardan kaynaklandığına kitapta ayrıca vurgulanmıştır. Buna ek olarak yönetici elitin vergilendirmeyi hem mali bir kaynak hem de politik bir araç olarak gördüğünü de bu bölümden anlamak mümkündür. Nitekim Köprülü Fazıl Mustafa Paşa gayrimüslimlerin düşman ile işbirliği içine girmesini engellemek için memnun olmadıkları müskirat vergisini düşürme yoluna gitmiştir.

“Osmanlida Müskirat Üretimi Ticareti ve Tüketimi 1792-1839” başlıklı son ana bölüm beş alt başlıktan oluşmaktadır. Müskirat kelimesinin etimolojisine değinilmekte ve tarihsel süreç içerisinde Avrupa'nın müskirat ile Endülüs Emevileri döneminde tanıştıkları ve Emevilerin "el kübül" dedikleri bu keyif verici maddeyi alcohol olarak kendi dillerinde kullanıma soktukları anlatılmaktadır. 
İmparatorluğun müskirat üretimine ve ticaretine odaklanan bu bölümde imparatorluk çapında üretimin gerçekleştiği bölgeler ve bu bölgelerde; üretimin nasıl gerçekleştiği, vergilendirmenin nasıl yapıldığı ve fiyatların nasıl değişiklik gösterdiği gibi konular farklı bölgelere göre ele alınmıştır. Evliya Çelebi, Joseph de Tournefort gibi yazarların görüşlerine de bu bölümde yer verilmiştir. Bu durum Anadolu, Rumeli ve Adalarda gerçekleştirilen şarap ve arak üretim miktarlarının okuyucuya sunulması ile daha da detaylandırılmaktadır. Bunu takip eden başlıklarda ticaretin analizi, İstanbul'un ihtiyaçlarını karşılayan bölgeler ve imparatorluğun fiskalist görüş ile müskirat ticaretine bakışı incelenmektedir.

Derviş Tuğrul Koyuncu'nun üç ana bölümden oluşan kitabını 13 adet tablo, 26 adet grafik, resimler ve şekillere ek Osmanlı Arşivi'nden birçok belge ile destekleyerek sadece bir anlatı tarihçiliği değil iktisat tarihi bilimine uygun olan bir iktisat tarihi çalışması kaleme aldığı açıktır. Konunun görsellerle, tablo ve grafiklerle desteklenmesi tezin incelemeye çalıştığı, müskiratın iktisadi ve ekonomik boyutunun anlaşılmasını kolaylaşı̧ıdığı, kitabın bir başka önemli özelliği olarak belirtilmelidir. Daha önceden incelenmemiş bir konunun sosyal, mali, siyasi, iktisadi ve tarihsel boyutlarının incelenmiş olması nedeniyle kitap sadece siyasi ve sosyal tarihe değil iktisadi tarihe de önemli katkılar yapmaktadır.

Bahadır Emre Küçükkalay Süleyman Demirel Üniversitesi 